\title{
Akt inhibitors induce apoptosis in chronic lymphocytic leukemia cells
}

\author{
Mercè de Frias, ${ }^{1}$ Daniel Iglesias-Serret, ${ }^{1}$ Ana M. Cosialls, ${ }^{1}$ Llorenç Coll-Mulet, ${ }^{1}$ Antonio F. Santidrián, ${ }^{1}$ \\ Diana M. González-Gironès, ${ }^{1}$ Esmeralda de la Banda, ${ }^{2}$ Gabriel Pons, ${ }^{1}$ and Joan Gil ${ }^{1}$
}

${ }^{1}$ Departament de Ciències Fisiològiques II, Institut d'Investigació Biomèdica de Bellvitge (IDIBELL), Universitat de Barcelona, L'Hospitalet de Llobregat, and '2Servei d'Hematologia, IDIBELL-Hospital de Bellvitge, L'Hospitalet de Llobregat, Spain

\section{ABSTRACT}

\section{Background}

The phosphatidylinositol-3-kinase/Akt pathway has been described to be critical in the survival of chronic lymphocytic leukemia cells. In this study we analyzed the effect of two selective chemical inhibitors of Akt (Akti-1/2 and A-443654) on the survival of chronic lymphocytic leukemia cells.

\section{Design and Methods}

Using cytometry we studied the cytotoxic effects of Akt inhibitors on peripheral B and $\mathrm{T}$ lymphocytes from patients with chronic lymphocytic leukemia and from healthy donors. We studied the changes induced by Akti-1/2 and A-443654 at the mRNA level by performing reverse transcriptase multiplex ligation-dependent probe amplification. We also studied the changes induced by both Akt inhibitors in some BCL-2 protein family members on chronic lymphocytic leukemia cells by western blotting. Moreover, we analyzed the cytotoxic effect of Akt inhibitors in patients' cells with deleted/mutated TP53.

\section{Results}

Both inhibitors induced apoptosis in chronic lymphocytic leukemia cells in a dose-dependent manner. Moreover, B cells from patients with chronic lymphocytic leukemia were more sensitive to Akt inhibitors than T cells from leukemic patients, and B or T cells from healthy donors. Survival factors for chronic lymphocytic leukemia cells, such as interleukin-4 and stromal cell-derived factor-1 $\alpha$, were not able to block the apoptosis induced by either Akt inhibitor. Akti-1/2 did not induce any change in the mRNA expression profile of genes involved in apoptosis, while A-443654 induced some changes, including an increase in NOXA and PUMA mRNA levels, suggesting the existence of additional targets for A-443654. Both inhibitors induced an increase in PUMA and NOXA protein levels, and a decrease in MCL-1 protein level. Moreover, Akti-1/2 and A-443654 induced apoptosis irrespective of TP53 status.

\section{Conclusions}

These results demonstrate that Akt inhibitors induce apoptosis of chronic lymphocytic leukemia cells and might be a new therapeutic option for the treatment of chronic lymphocytic leukemia.

Key words: Akt, chronic lymphocytic leukemia, apoptosis.

Citation: de Frias $M$, Iglesias-Serret D, Cosialls AM, Coll-Mulet L, Santidrián AF, González Gironès DM, de la Banda E, Pons G, and Gil J. Akt inhibitors induce apoptosis in chronic lymphocytic leukemia cells. Haematologica 2009; 94:1698-1707. doi:10.3324/haematol.2008.004028

(C)2009 Ferrata Storti Foundation. This is an open-access paper.

\section{Acknowledgments: the authors thank Alba Pérez Perarnau, Camila Rubio and Dr. Esther Castaño for helpful discussions and suggestions; Michael Maudsley for language assistance; and Abbott for kindly providing A-443654. We also thank the Unitat de Biologia and the Unitat de Genòmica from the Serveis Cientificotècnics at the Universitat de Barcelona for their technical support. \\ Funding: this study was supported by grants from the Ministerio de Ciencia e Innovación and FEDER (SAF2007-60964), the Ministerio de Sanidad y Consumo (ISCIII- RTICC RD06/0020), and the AGAUR-Generalitat de Catalunya (2005SGR-00549). $M d e F$ is a recipient of a fellowship from the AGAUR- Generalitat de Catalunya, AMC and DMGG are recipients of research fellowships from the Ministerio de Educación y Ciencia. DIS and LCM are recipi- ents of fellowships from the José Carreras International Leukemia Foundation (FIJC-07/ESP-FCAJAMADRID).}

Manuscript received November 25,2008 . Revised version arrived June 4, 2009. Manuscript accepted June 10, 2009.

\section{Correspondence:}

Joan Gil, Ph.D., Departament de Ciències Fisiològiques II, IDIBELLUniversitat de Barcelona, Campus de Bellvitge, Pavelló de Govern, $4^{a}$ planta, E-08907 L'Hospitalet de Llobregat, Barcelona, Spain. E-mail: jgil@idibell.cat

The online version of this article contains a supplementary appendix. 


\section{Introduction}

The phosphatidylinositol-3-kinase (PI3K) pathway has been described to be critical in the survival of chronic lymphocytic leukemia (CLL) cells. ${ }^{1-11}$ PI3K phosphorylates the D-3 position of phosphatidylinositol, phosphatidylinositol 4-phosphate and phosphatidylinositol 4,5-diphosphate. The cellular levels of PI3K products are controlled by the balance between PI3K activity and the phosphatase activity of PTEN (phosphatase and tensin homolog deleted on chromosome ten). ${ }^{12}$ Interestingly, PTEN protein is reduced or not detected in $48 \%$ of patients with CLL. ${ }^{13}$

One of the most important targets of PI3K products is the serine-threonine kinase Akt, also known as protein kinase $\mathrm{B}(\mathrm{PKB}){ }^{14}$ Akt resides in the cytosol in a low-activity conformation, and it is activated through recruitment to cell membranes by PI3K lipid products and phosphorylation at Thr308 and Ser473. Once Akt is activated, it is able to promote cell survival through phosphorylation and inactivation of key components in the apoptotic cascade. Akt substrates include the members of the Forkhead family of transcription factors $^{15}$ and glycogen synthase kinase-3 (GSK-3), ${ }^{16}$ which are inhibited by Akt. Furthermore, GSK-3 inhibition induces the up-regulation of the anti-apoptotic protein MCL-1. ${ }^{16}$ Activation of the PI3K/Akt pathway in CLL cells induces the phosphorylation of the Forkhead family member FoxO3a and GSK-3, and an increase in MCL-1 protein, while inhibition of PI3K induces a loss of cell viability, dephosphorylation of FoxO3a and GSK-3, and a decrease in the level of MCL-1 protein. ${ }^{3,4,11}$ Importantly, a stronger activation of Akt pathway has been related to a higher capacity for cell cycle progression in CLL cells from patients with progressive disease. ${ }^{17}$ All together, these studies suggest that Akt plays a prominent role in the survival of CLL; however, the effect of selective chemical Akt inhibitors on the survival of CLL cells has not been reported yet.

A-443654 is a potent, ATP competitive and reversible inhibitor of Akt catalyzed phosphorylation activity. It is a pan-Akt inhibitor and has equal potency against Akt1, Akt2 or Akt3. ${ }^{18,19}$ Together with the decrease in phosphorylation of Akt targets, a concomitant increase in the phosphorylation of Ser473 and Thr308 Akt residues has been observed. This increase is PI3K-dependent, as demonstrated by the fact that incubating the cells with LY294002 blocks it. ${ }^{20}$ Recently, it was reported that this inhibitor also inhibits other protein kinases, albeit with slightly lower potency, such as PKA, PRK2, MSK1 and DYRK1A. ${ }^{21}$ It was also reported that Akti-1/2, an ATP non-competitive Akt inhibitor, was a highly selective Akt inhibitor, blocking Akt1 and Akt2 but not Akt3 activity; the pleckstrin homology domain is required for the activity of this inhibitor. ${ }^{22,23}$

In this study we examined the effect of these two Akt inhibitors on CLL cells.

\section{Design and Methods}

\section{Patients with chronic lymphocytic leukemia, healthy donors and cell isolation}

Samples from patients with CLL (Table 1) or healthy donors were studied. CLL was diagnosed according to standard clinical and laboratory criteria. Blood samples were obtained from the Hospital de Bellvitge, L'Hospitalet de Llobregat, Spain. Written informed consent was obtained from all patients in accordance with the Hospital de Bellvitge Ethical Committee's requirements.

Mononuclear cells from peripheral blood samples were isolated by centrifugation on a Ficoll-Hypaque (Seromed, Berlin, Germany) gradient and cryopreserved in liquid nitrogen in the presence of $10 \%$ dimethyl sulfoxide (Sigma-Aldrich, Steinheim, Germany), and are referred to as CLL cells throughout this article. B-cells (CD19+ cells) were purified from samples from three patients (n. 49, 50 and 51) by using the RosetteSep Human B Cell Enrichment Cocktail (StemCell Technologies, Vancouver, Canada). Blood samples or isolated mononuclear cells were incubated with RosetteSep Human B Cell Enrichment Cocktail at $50 \mu \mathrm{L} / \mathrm{mL}$ for $20 \mathrm{~min}$ prior to centrifugation on a FicollHypaque, according to the manufacturer's protocol.

\section{Immunological and genetic analyses}

CD38 and ZAP-70 were determined by flow cytometry in fixed cells with conjugated antibodies (PE clone HB7, Becton Dickinson, Franklin Lakes, NJ, USA and Alexa-Fluor 488, Caltag Laboratories, Burlingame, CA, USA, respectively). CD19 was determined by flow cytometry with a conjugated antibody [phycoerythrin (PE)-conjugated anti-CD19; Becton Dickinson].

Genomic alterations were detected by fluorescence in situ hybridization (FISH). Fluorescent-labeled DNA probes were used in interphase cytogenetic analyses. Locus-specific probes (LSI P53/Spectrum-Orange, LSI ATM/Spectrum-Green, LSI 13S319/Spectrum-Orange, LSI 13q34/SpectrumAqua) were used to determine loss of these genetic regions within interphase nuclei. Trisomy 12 was detected in interphase nuclei using a chromosomal centromere enumeration probe (CEP) labeled with Spectrum-Green. These five probes are packaged together in a commercially available kit (Vysis Chronic Lymphocytic Leukemia Multicolor Kit) and were used in accordance with the manufacturer's specifications. Cells were fixed with fresh fixative before placement onto slides. The probe mixture was applied directly to slides. These slides were denaturated at $74^{\circ} \mathrm{C}$ for $2 \mathrm{~min}$ and incubated overnight at $37^{\circ} \mathrm{C}$. Slides were then washed with $0.4 \mathrm{x}$ saline sodium citrate $-0.3 \%$ nonidet $\mathrm{P}-40(\mathrm{NP}-40)$ at $73 \pm 1^{\circ} \mathrm{C}$ for $2 \mathrm{~min}$ and $2 \times$ saline sodium citrate $-0.1 \%$ nonidet P- 40 at room temperature for $1 \mathrm{~min}$. 4'6-diamidino-2phenylindole (DAPI) II counterstain was applied to the target area. Slides were stored at $20^{\circ} \mathrm{C}$ in the dark. Two hundred nuclei were analyzed for each probe, using a NIKON fluorescent microscope. Cut-off levels used were $5 \%$ for CEP 12 and $7 \%$ for locus-specific probes. The karyotype of all samples was determined. 
Table 1. Characteristics of the chronic lymphocytic leukemia patients studied.

\begin{tabular}{|c|c|c|c|c|c|c|c|c|c|c|}
\hline Patient & $\begin{array}{l}\text { Age/Sex } \\
\left(x 10^{\circ} / L\right)\end{array}$ & WBC & $\begin{array}{c}\text { Lymphocytes } \\
(\%)\end{array}$ & $\begin{array}{c}\text { CD19+ } \\
(\%)\end{array}$ & $\begin{array}{l}\text { CD } 38 * \\
(\%)\end{array}$ & $\begin{array}{l}\text { ZAP70 } \\
(\%)\end{array}$ & $\begin{array}{l}\text { Cenomic } \\
\text { alterations }\end{array}$ & $F / T$ & $\begin{array}{l}E_{50}(\mu M) \\
\text { Akti-1/2 }\end{array}$ & $\begin{array}{l}E_{50}(\mu M) \\
A-443654\end{array}$ \\
\hline 1 & $75 / \mathrm{F}$ & 41 & 78 & 77 & 2 & ND & ND & $\mathrm{F}$ & & \\
\hline 2 & $63 / \mathrm{F}$ & 71 & 84 & 72 & 28 & 53 & ND & $\mathrm{F}$ & 7.5 & \\
\hline 3 & $64 / \mathrm{F}$ & 100 & 76 & 96 & 87 & 40 & del13q, del17p & $\mathrm{T}$ & & \\
\hline 4 & $72 / \mathrm{M}$ & 49 & 96 & 84 & 2 & 0.56 & del13q & $\mathrm{F}$ & & \\
\hline 5 & $76 / \mathrm{F}$ & 27 & 84 & 75 & 15 & 3 & ND & $\mathrm{F}$ & 9 & 0.75 \\
\hline 6 & 71/M & 94 & 94 & 88 & 16 & 26 & normal & $\mathrm{F}$ & & 0.7 \\
\hline 7 & $61 / \mathrm{M}$ & 76 & 84 & 82 & 2 & 6 & ND & $\mathrm{F}$ & & 0.6 \\
\hline 8 & $70 / \mathrm{M}$ & 98 & 94 & 86 & 2 & 5 & del17p & $\mathrm{F}$ & 8 & 0.6 \\
\hline 9 & $77 / \mathrm{F}$ & 137 & 68 & 90 & 10 & 14 & normal & $\mathrm{F}$ & & 0.45 \\
\hline 10 & $73 / \mathrm{F}$ & 82 & 88 & 80 & 20 & 5 & ND & $\mathrm{F}$ & & 0.65 \\
\hline 11 & $74 / \mathrm{F}$ & 31 & 93 & 89 & ND & 14 & ND & $\mathrm{F}$ & & 0.4 \\
\hline 12 & $65 / \mathrm{M}$ & 16 & 93 & 83 & 91 & 38 & normal & $\mathrm{F}$ & & 0.5 \\
\hline 13 & $57 / \mathrm{M}$ & 31 & 84 & 79 & 50 & 2 & dell1q & $\mathrm{F}$ & & 0.8 \\
\hline 14 & $61 / \mathrm{F}$ & 90 & 96 & 80 & 9 & 5 & normal & $\mathrm{T}$ & 12.5 & 0.65 \\
\hline 15 & $50 / \mathrm{M}$ & 60 & 94 & 80 & 30 & 6 & del13q & $\mathrm{T}$ & 10 & 0.85 \\
\hline 16 & $71 / \mathrm{F}$ & 77 & 84 & 86 & 6 & 12 & normal & $\mathrm{T}$ & 13 & 0.75 \\
\hline 17 & $66 / \mathrm{F}$ & 91 & 95 & 73 & 20 & 28 & del13q & $\mathrm{F}$ & 8.5 & 0.55 \\
\hline 18 & $66 / F$ & 44 & 86 & 80 & 4 & 14 & ND & $\mathrm{T}$ & 11 & 0.75 \\
\hline 19 & $81 / \mathrm{F}$ & 76 & 92 & 85 & 51 & 27 & ND & $\mathrm{T}$ & 8 & 0.45 \\
\hline 20 & $70 / \mathrm{M}$ & 58 & 94 & 70 & 12 & 10 & del13q & $\mathrm{F}$ & 12 & \\
\hline 21 & $82 / \mathrm{M}$ & 67 & 80 & 80 & 78 & 0.05 & ND & $\mathrm{F}$ & 13 & \\
\hline 22 & $75 / \mathrm{F}$ & 93 & 84 & 90 & 4 & 0,64 & del13q & $\mathrm{F}$ & 15 & \\
\hline 23 & $85 / \mathrm{F}$ & 100 & 80 & 80 & 12 & 22 & del13q & $\mathrm{F}$ & 7 & \\
\hline 24 & $63 / \mathrm{F}$ & 56 & 91 & 83 & 13 & 1,5 & normal & $\mathrm{T}$ & & 0.4 \\
\hline 25 & $75 / \mathrm{M}$ & 83 & 89 & 82 & 35 & 15 & del13q & $\mathrm{F}$ & & \\
\hline 26 & $53 / \mathrm{M}$ & 113 & 94 & 94 & 51 & 10 & del13q & $\mathrm{T}$ & & 0.5 \\
\hline 27 & $59 / \mathrm{F}$ & 89 & 90 & 80 & 7 & 34 & normal & $\mathrm{F}$ & 5 & 0.75 \\
\hline 28 & $81 / \mathrm{F}$ & 22 & 92 & 72 & 5 & 3 & ND & $\mathrm{F}$ & 6 & 0.65 \\
\hline 29 & $86 / \mathrm{M}$ & 22 & 89 & 71 & 28 & 42 & ND & $\mathrm{F}$ & & 0.7 \\
\hline 30 & $69 / \mathrm{M}$ & 53 & 87 & 74 & ND & ND & del13q & $\mathrm{T}$ & & 0.5 \\
\hline 31 & $56 / \mathrm{M}$ & 55 & 95 & 72 & 70 & 53 & del13q, del11q & $\mathrm{T}$ & 12 & \\
\hline 32 & $54 / \mathrm{M}$ & 30 & 73 & 48 & 13 & 54 & ND & $\mathrm{T}$ & 12.5 & 0.8 \\
\hline 33 & $71 / \mathrm{F}$ & 54 & 74 & 80 & 9 & 44 & del13q & $\mathrm{T}$ & 10 & 0.85 \\
\hline 34 & $81 / \mathrm{F}$ & 31 & 83 & 79 & 7 & 7 & normal & $\mathrm{T}$ & & \\
\hline 35 & $72 / \mathrm{M}$ & 37 & 86 & 74 & 2 & 1 & normal & $\mathrm{F}$ & & \\
\hline 36 & $74 / \mathrm{M}$ & 590 & 97 & ND & 24 & 52 & tris12 & $\mathrm{T}$ & & \\
\hline 37 & $85 / \mathrm{M}$ & 31 & 87 & 80 & 30 & 50 & ND & $\mathrm{F}$ & & 0.4 \\
\hline 38 & 71/M & 48 & 87 & 87 & 18 & 4 & normal & $\mathrm{F}$ & & \\
\hline 39 & $54 / \mathrm{M}$ & 132 & 93 & 88 & 19 & 14 & normal & $\mathrm{T}$ & & 0.5 \\
\hline 40 & $70 / \mathrm{M}$ & 131 & 98 & 86 & 93 & 39 & dell7p, del11q & $\mathrm{T}$ & & \\
\hline 41 & $73 / \mathrm{F}$ & 18 & 86 & ND & 24 & 29 & del17p & $\mathrm{T}$ & 5 & \\
\hline 42 & $81 / \mathrm{M}$ & 24 & 95 & 85 & 60 & 31 & tris12, del11q & $\mathrm{T}$ & & \\
\hline 43 & $66 / \mathrm{F}$ & 44 & 86 & 80 & 4 & 14 & ND & $\mathrm{T}$ & 12 & 0.8 \\
\hline 44 & $80 / \mathrm{M}$ & 96 & 93 & 80 & 2 & 0.48 & del13q, del11q & $\mathrm{T}$ & & \\
\hline 45 & $74 / \mathrm{F}$ & 43 & 94 & 87 & 10 & 8 & del13q & $\mathrm{T}$ & & \\
\hline 46 & $58 / \mathrm{M}$ & 74 & 89 & 90 & 24 & 6 & dell3q & $\mathrm{T}$ & & \\
\hline 47 & $70 / \mathrm{M}$ & 79 & 84 & 91 & ND & ND & del13q & $\mathrm{T}$ & & \\
\hline 48 & 78/M & 85 & 95 & 84 & ND & ND & tris12 & $\mathrm{T}$ & & \\
\hline 49 & $64 / \mathrm{M}$ & 88 & 95 & 97 & ND & 10 & del13q & $\mathrm{F}$ & & \\
\hline 50 & $67 / \mathrm{F}$ & 88 & 90 & 96 & 20 & 28 & del13q & $\mathrm{F}$ & & \\
\hline 51 & $72 / \mathrm{M}$ & 51 & 92 & 97 & 7 & 26 & $\mathrm{ND}$ & $\mathrm{F}$ & & \\
\hline
\end{tabular}

WBC: white blood cell count; F: female; M: male; del: deletion; tris: trisomy and ND: not determined; F: fresh cells; $T$ : frozen-thawed cells. 


\section{Reagents}

Akti-1/2 (previously known as Akt-I-1/2) was purchased from Calbiochem-Novabiochem (San Diego, CA, USA), A-443654 was kindly provided by Abbott (North Chicago, IL, USA), recombinant human interleukin-4 (IL-4) and stromal cell-derived factor- $1 \alpha$ (SDF$1 \alpha)$ were purchased from Immunotools (Friesoythe, Germany), annexin V-fluorescein isothiocyanate and propidium iodide were from Bender MedSystems (Vienna, Austria). Nutlin-3a was provided by Hoffmann-La Roche. Z-VAD.fmk was purchased from Bachem (Bubendorf, Switzerland). Ethanol and RNase A were from Sigma-Aldrich.

\section{Cell culture}

Lymphocytes were cultured immediately after thawing or isolation in RPMI 1640 culture medium supplemented with $10 \%$ heat-inactivated fetal bovine serum, 2 $\mathrm{mM}$ glutamine, $100 \mathrm{U}$ penicillin and $100 \mathrm{ng} / \mathrm{mL}$ streptomycin at $37^{\circ} \mathrm{C}$ in a humidified atmosphere containing $5 \% \mathrm{CO}_{2}$. To avoid differences in cell viability due to the cell concentration, flow cytometry experiments were performed at a concentration of $1 \times 10^{6}$ cells $/ \mathrm{mL}$, whereas the concentration used for reverse transcriptase multiplex ligation-dependent probe amplification (RT-MLPA) and the experiments to obtain cell extracts to perform western blotting was 2.5 to $3 \times 10^{6}$ cells $/ \mathrm{mL}$.

\section{Analysis of apoptosis by flow cytometry}

Apoptosis was assessed by exposure of phosphatidylserine and membrane integrity. This was determined by annexin V-fluorescein isothiocyanate and propidium iodide double staining. Flow cytometric analysis was performed using FACSCalibur and CellQuest software (Becton Dickinson), as described previously. ${ }^{24}$ Cell viability was measured as the percentage of annexin $\mathrm{V}$ and propidium iodide doublenegative cells. The results of flow cytometric analysis of three representative samples are shown in Online Supplementary Figure S1A.

To analyze apoptosis in $\mathrm{T}$ cells and $\mathrm{B}$ cells from the samples, $5 \times 10^{5}$ cells were incubated for $24 \mathrm{~h}$ with the indicated factors. Cells were then washed in annexinbinding buffer, and incubated in $50 \mu \mathrm{L}$ annexin-binding buffer with allophycocyanin-conjugated anti-CD3 and phycoerythrin-conjugated anti-CD19 from Becton Dickinson, for $10 \mathrm{~min}$ in the dark. Cells were then diluted with annexin-binding buffer to a volume of $150 \mu \mathrm{L}$ and incubated with $1 \mu \mathrm{L}$ annexin V-fluorescein isothiocyanate for $15 \mathrm{~min}$ in the dark. Cells were analyzed using FACSCalibur and CellQuest software. Results of flow cytometric analysis of one CLL sample and one sample from a healthy donor are shown in Online Supplementary Figure S1B.

Apoptosis in T cells and B cells was also assessed by subdiploid DNA analysis. Briefly, $1 \times 10^{6}$ cells were harvested, washed twice in phosphate-buffered saline containing $1 \%$ fetal bovine serum (PBS/1\% FBS) and fixed in $70 \%$ ethanol. The cells were centrifuged, washed in $\mathrm{PBS} / 1 \% \mathrm{FBS}$, and resuspended in $0.5 \mathrm{~mL}$ $\mathrm{PBS} / 1 \% \mathrm{FBS}$, containing allophycocyanin-conjugated anti-CD3 or allophycocyanin-conjugated anti-CD19. Tubes were incubated for $20 \mathrm{~min}$ at room temperature in the dark and then propidium iodide $(50 \mu \mathrm{g} / \mathrm{mL})$ and RNase A $(100 \mu \mathrm{g} / \mathrm{mL})$ were added and incubated for 30 min at room temperature in the dark before flow cytometry analysis to identify the sub-Go peak corresponding to apoptosis in $\mathrm{CD}^{+}$or $\mathrm{CD}^{1} 9^{+}$cells. Cells were analyzed using FACSCalibur and CellQuest software.

\section{Western blot analysis}

Cells were lysed with Laemmli sample buffer, and western blotting was performed as described previously. ${ }^{2}$ We used antibodies against p53 (Ab-5, Neomarkers, Fremont, CA, USA), MCL-1 and Akt (Santa Cruz Biotechnology, Santa Cruz, CA, USA), BCL-2 (Dako, A/S, Glostrup, Denmark), PUMA and NOXA (Abcam, Cambridge, UK), P-Ser473-Akt, PGSK- $3 \alpha / \beta$ and P-FoxO1/FoxO3a (Cell Signaling Technologies, Beverly, MA, USA), and $\beta$-actin (SigmaAldrich). Antibody binding was detected using a secondary antibody conjugated to horseradish peroxidase and an enhanced chemiluminescence detection system (Amersham, Buckinghamshire, UK).

\section{Reverse transcriptase multiplex ligation-dependent probe amplification}

RNA was analyzed by RT-MLPA using a SALSA MLPA KIT R011 Apoptosis mRNA from MRC-Holland (Amsterdam, The Netherlands) for the simultaneous detection of 38 mRNA molecules. ${ }^{25}$ In brief, RNA samples (200 ng total RNA) were first reverse transcribed using a gene-specific probe mix. The resulting cDNA was annealed overnight at $60^{\circ} \mathrm{C}$ to the MLPA probe mix. Annealed oligonucleotides were ligated by adding Ligase-65 (MRC-Holland, Amsterdam, The Netherlands) and incubated at $54^{\circ} \mathrm{C}$ for $15 \mathrm{~min}$. Ligation products were amplified by polymerase chain reaction (PCR; 35 cycles, $30 \mathrm{~s}$ at $95^{\circ} \mathrm{C} ; 30 \mathrm{~s}$ at $60^{\circ} \mathrm{C}$, and $1 \mathrm{~min}$ at $72^{\circ} \mathrm{C}$ ) with one unlabeled and one FAM labeled primer. The final PCR fragments amplified were separated by capillary electrophoresis on a 48-capillary ABI-Prism 3730 Genetic Analyzer (Applied Biosystems/Hitachi, Foster City, CA, USA). Peak area and height were measured using GeneScan analysis software (Applied Biosystems). The sum of all peak data was set at 100\% to normalize for fluctuations in total signal between samples, and individual peaks were calculated relative to the $100 \%$ value.

\section{Statistical analysis}

Results are shown as the mean \pm standard error of the mean (SEM) of values obtained in independent experiments. The paired Student's $t$ test was used to compare differences between paired samples. Data were analyzed using the SPSS 14.0 software package (Chicago, IL, USA). 


\section{Results}

\section{Akti-1/2 and A-443654 inhibit Akt in chronic lymphocytic leukemia cells}

To assess the effect of Akti-1/2 and A-443654 on Akt activity in CLL cells, we examined the phosphorylation status of Akt or Akt substrates which are used to assess the activation status of Akt. Akti-1/2 inhibited Ser473 phosphorylation in a dose-dependent manner (Figure 1A). As previously described for other cell types, ${ }^{18,20} \mathrm{~A}$ 443654 induced an increase in Ser473 phosphorylation. In order to confirm that A-443654 was inhibiting Akt, we analyzed the status of the Akt substrates GSK3 $\alpha / \beta$ and FoxO1/FoxO3a. Both inhibitors reduced the phosphorylation of GSK3 $\alpha / \beta$ and FoxO1/FoxO3a (Figure $1 B)$, demonstrating that they inhibited Akt activity.

\section{Akt inhibitors induce apoptosis in chronic lymphocytic leukemia cells}

To examine the ability of Akt inhibitors to induce apoptosis in CLL cells, we incubated CLL cells with a range of concentrations of Akti-1/2 $(0.5-20 \mu \mathrm{M})$ and A$443654(0.1-1 \mu \mathrm{M})$ for $24 \mathrm{~h}$ and measured cell viability. Both inhibitors induced apoptosis in a dose-dependent manner (Figure 2A and 2B) and in a time-dependent manner (Online Supplementary Figure S2). The half-maximal effective concentration (EC50) was $9.85 \pm 0.67 \mu \mathrm{M}$ (range, 5 to $15 \mu \mathrm{M}$ ) for Akti-1/2, and $0.63 \pm 0.03 \mu \mathrm{M}$ (range, 0.40 to $0.85 \mu \mathrm{M}$ ) for A-443654. Similar results were obtained in purified CD19+ CLL cells (Online Supplementary Figure S3). Akti-1/2 and A-443654 induced apoptosis in all the analyzed samples, independently of sex, ZAP70 status, CD38 status or genomic alterations (data not shown).

\section{Differential effect of Akt inhibitors on B and T cells from patients with chronic lymphocytic leukemia and healthy donors}

Next, we analyzed the sensitivity of normal B and $T$ cells to Akt inhibitors, in terms of induction of apoptosis. The number of apoptotic $\mathrm{T}$ cells $\left(\mathrm{CD}^{+}\right.$cells) was measured in CLL samples and blood samples from healthy donors exposed to several doses of Akti-1/2
A

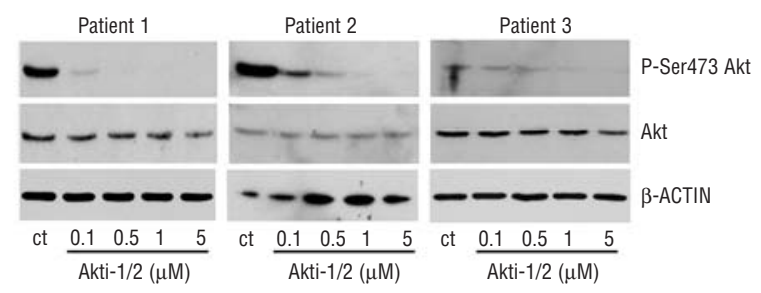

B
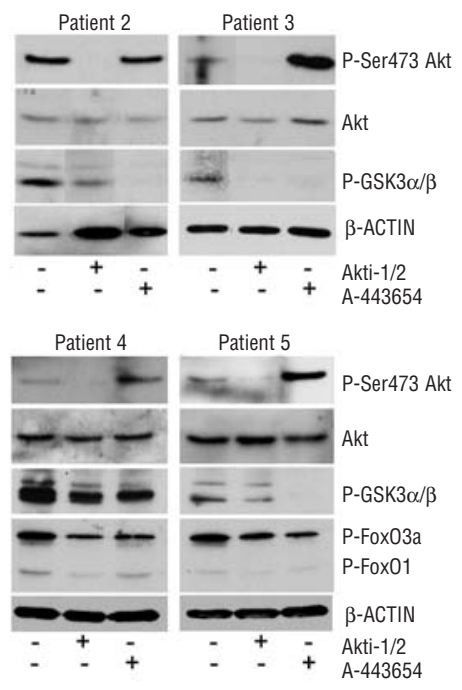

Figure 1. Akti-1/2 and A-443654 effects on the phosphorylation of Akt and Akt substrates. CLL cells were incubated with or without a range of doses of Akti-1/2 for $2 \mathrm{~h}$. (A) Cells were lysed and whole extracts were analyzed by western blot as described in the Design and Methods section. Results from three patients are shown $(n=3)$. (B) CLL cells were incubated with or without $5 \mu M$ Akti-1/2 and $0.5 \mu \mathrm{M}$ (patients 2, 4 and 5) or $1 \mu \mathrm{M}$ (patient 3) A443654 for $2 \mathrm{~h}$. Cells were lysed and whole extracts were analyzed by western blot as described in the Design and Methods section. Results from four representative patients are shown $(n=9)$.
A

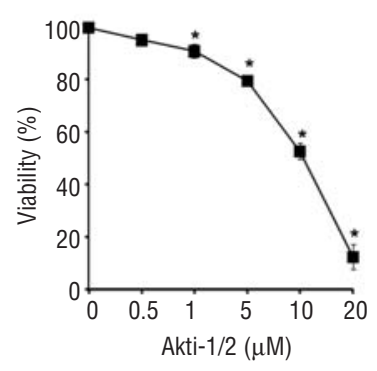

C

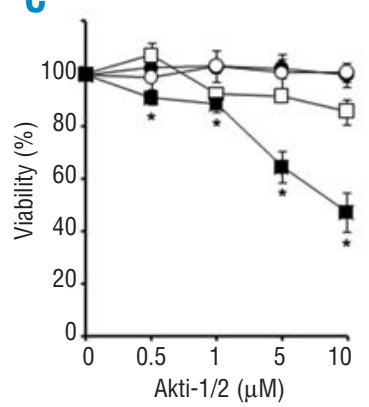

D

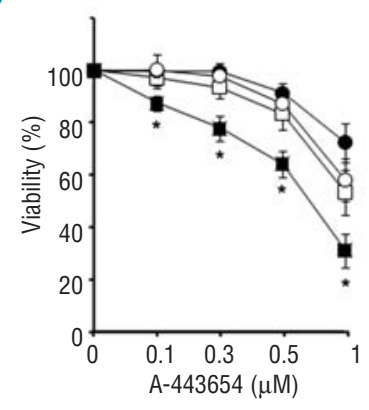

Figure 2. Cytotoxic effect of Akt inhibitors on CLL cells and on peripheral blood lymphocytes (PBL) from healthy donors. Cells from CLL patients were incubated for $24 \mathrm{~h}$ with or without various doses of Akti-1/2 (A, n=15) and A-443654 (B, n=15). Viability was measured by analysis of phosphatidylserine exposure and PI uptake as described in the Design and Methods section. Cells from CLL patients and healthy donors were incubated for $24 \mathrm{~h}$ with or without various doses of Akti-1/2 (C, $n=9$ and $n=3$, respectively) and A-443654 (D, $n=13$ and $n=8$, respectively). Viability was measured as non-apoptotic $\mathrm{CD}^{+} / \mathrm{CD} 19^{-} \mathrm{T}$ cells from PBL $(\mathrm{O})$ and CLL $(O)$ or CD3 $-/ \operatorname{CD}_{1}{ }^{+}$B cells from PBL $(\square)$ and CLL ( $\square$ ) as described in the Design and Methods section. Viability is expressed as the percentage of the viability of untreated cells. Data are shown as the mean value \pm SEM. ${ }^{*} p<0.005$, treated versus untreated cells $(A, B)$, or $B$ cells versus $T$ cells from patients with CLL (C, D). 
(up to $10 \mu \mathrm{M}$ ) and A-443654 (up to $1 \mu \mathrm{M}$ ) for $24 \mathrm{~h}$. Incubation with $5 \mu \mathrm{M}$ Akti-1/2 reduced the percentage of viable CLL cells to $64.64 \pm 6.12 \%$. In contrast, the percentage of viable $\mathrm{T}$ cells from CLL samples was $102.4 \pm 3.46 \%$. Interestingly, B and $T$ cells derived from healthy donors were resistant to Akti-1/2-induced apoptosis. Thus, after incubation with $5 \mu \mathrm{M}$ Akti-1/2 the percentage of viable B cells and T cells were $91.6 \pm$ $2.1 \%$ and $100.7 \pm 7.2 \%$, respectively (Figure 2C). Similar results were obtained in the treatment of CLL cells and cells from healthy donors with A-443654, but the difference between CLL cells and B or T cells from healthy donors was less pronounced than in the case of Akti-1/2. Incubation with $0.5 \mu \mathrm{M}$ A-443654 reduced the percentage of viable CLL cells to $64.2 \pm 4.9 \%$. In contrast, the percentage of viable $\mathrm{T}$ cells was $91.3 \pm 3.7 \%$. Furthermore, $B$ and $T$ cells derived from
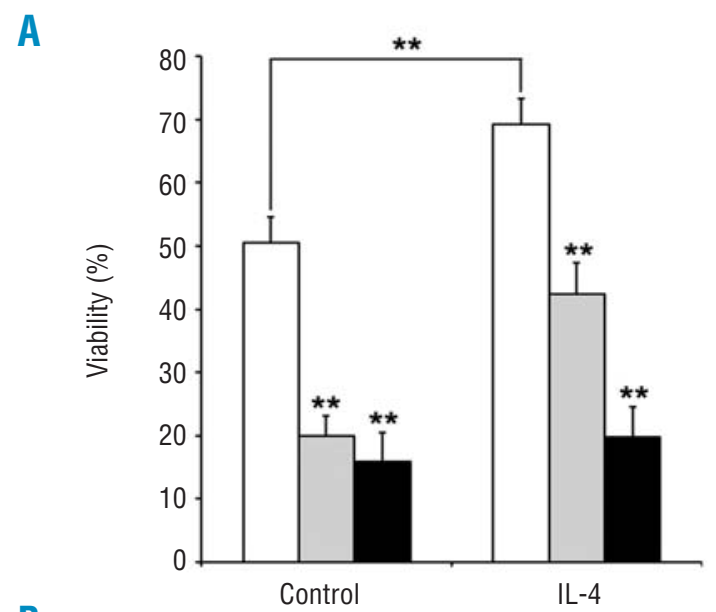

B

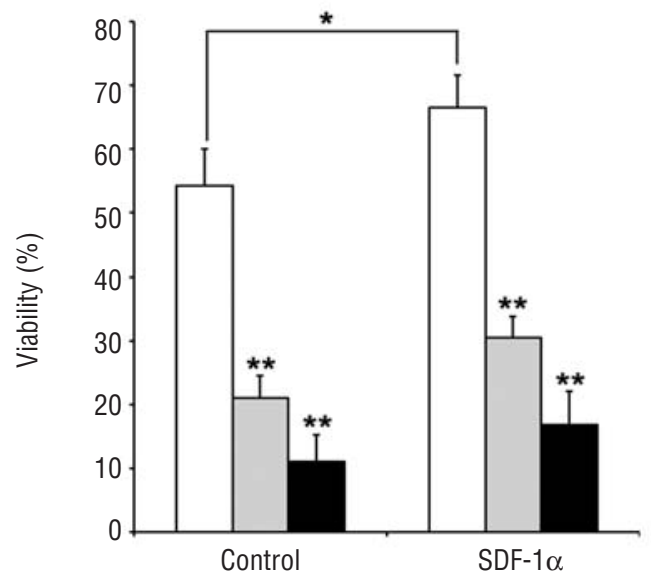

Figure 3. Effect of survival signals on the apoptotic activity of Akt inhibitors. CLL cells were untreated or treated with $10 \mathrm{ng} / \mathrm{mL}$ IL-4 $(A, n=10)$ or $50 \mathrm{ng} / \mathrm{mL}$ SDF-1 $\alpha(B, n=7)$ without (white filled bars) or with $10 \mu \mathrm{M}$ Akti-1/2 (gray filled bars) or $0.5 \mu \mathrm{M} A$ 443654 (black filled bars) for $48 \mathrm{~h}$. Viability was measured by analysis of phosphatidylserine exposure and propidium iodide uptake as described in the Design and Methods section. Data are shown as the mean value \pm SEM. $* * p<0.001$ control versus IL-4 and Akt inhibitors treated cells versus control, IL-4 or SDF-1 $\alpha$; ${ }^{*} p<0.01$ control versus SDF-1 $\alpha$-treated cells. healthy donors were less sensitive than cells from CLL samples to A-443654-induced apoptosis. Thus, after incubation with $0.5 \mu \mathrm{M} \mathrm{A}-443654$ the percentages of viable $B$ and $T$ cells were $83.4 \pm 5.8 \%$ and $87.1 \pm 5.9 \%$, respectively (Figure 2D). Similar results were obtained when CLL cells and cells from healthy donors were treated for $48 \mathrm{~h}$ with both Akt inhibitors (Online Supplementary Figure S4). We confirmed this differential induction of apoptosis between CLL cells and normal lymphocytes by performing an analysis of the DNA content. We observed that CLL cells were more sensitive than $T$ cells and normal $B$ cells to the Akt inhibitor-induced increase in sub-Go peak (Online Supplementary Figure S5). These results indicate that B cells from CLL samples are more sensitive than normal $\mathrm{B}$ and $\mathrm{T}$ cells to Akt inhibitor-induced apoptosis.

\section{Effect of survival factors in combination with Akt inhibitors}

We studied the effect of two well-known survival factors in CLL cells, IL- $4^{26}$ and SDF- $1 \alpha,{ }^{27}$ in combination with Akt inhibitors. We used selected CLL samples in which these factors induced a survival effect. Thus, we treated CLL cells with $10 \mathrm{ng} / \mathrm{mL}$ IL-4 (Figure

A

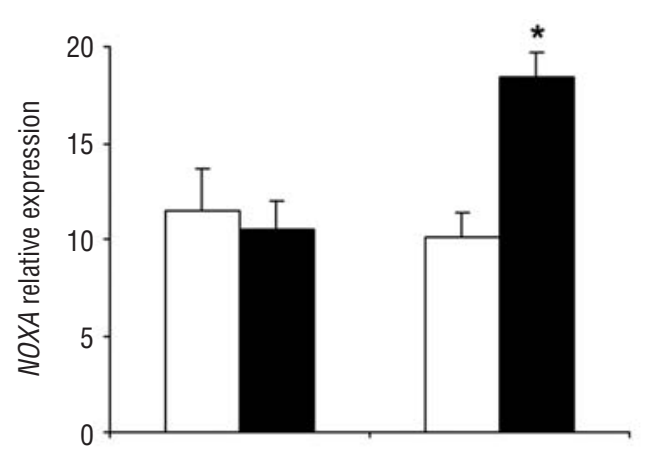

B

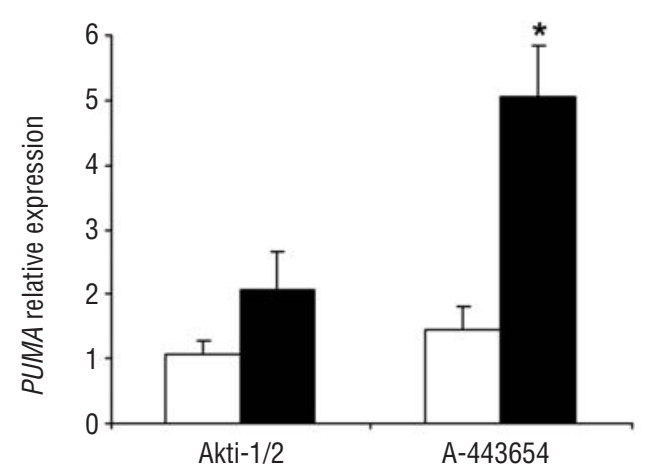

Figure 4. Apoptosis-related gene expression profile induced by Akti-1/2 and A-443654. Cells from CLL patients were untreated (open bars) or treated with $5 \mu \mathrm{M}$ Akti-1/2 or $0.5 \mu \mathrm{M}$ A-443654 (black filled bars) for $24 \mathrm{~h}$. Cells were lysed, and NOXA (A) and PUMA (B) mRNA expression was analyzed by RT-MLPA as described in the Design and Methods section. The results are shown as the mean value \pm SEM of four and eight different experiments for Akti-1/2 and A-443654, respectively. ${ }^{*} p<0.005$ treated versus untreated cells. 
$3 \mathrm{~A}$ ) or $50 \mathrm{ng} / \mathrm{mL} \mathrm{SDF}-1 \alpha$ (Figure $3 \mathrm{~B}$ ) and with or without $10 \mu \mathrm{M}$ Akti-1/2 or $0.5 \mu \mathrm{M}$ A-443654 for $48 \mathrm{~h}$, and then measured cell viability. Neither IL-4 nor SDF-1 $\alpha$ was able to inhibit the apoptosis induced by both Akt inhibitors. These results show that Akt inhibitors can induce apoptosis in CLL cells even in the presence of survival signals.

\section{Characterization of Akt inhibitor-induced apoptosis in chronic lymphocytic leukemia}

We investigated the effect of Akt inhibitors on the overall apoptosis mRNA expression profile by performing RT-MLPA. ${ }^{25}$ Treatment of CLL cells with $5 \mu \mathrm{M}$
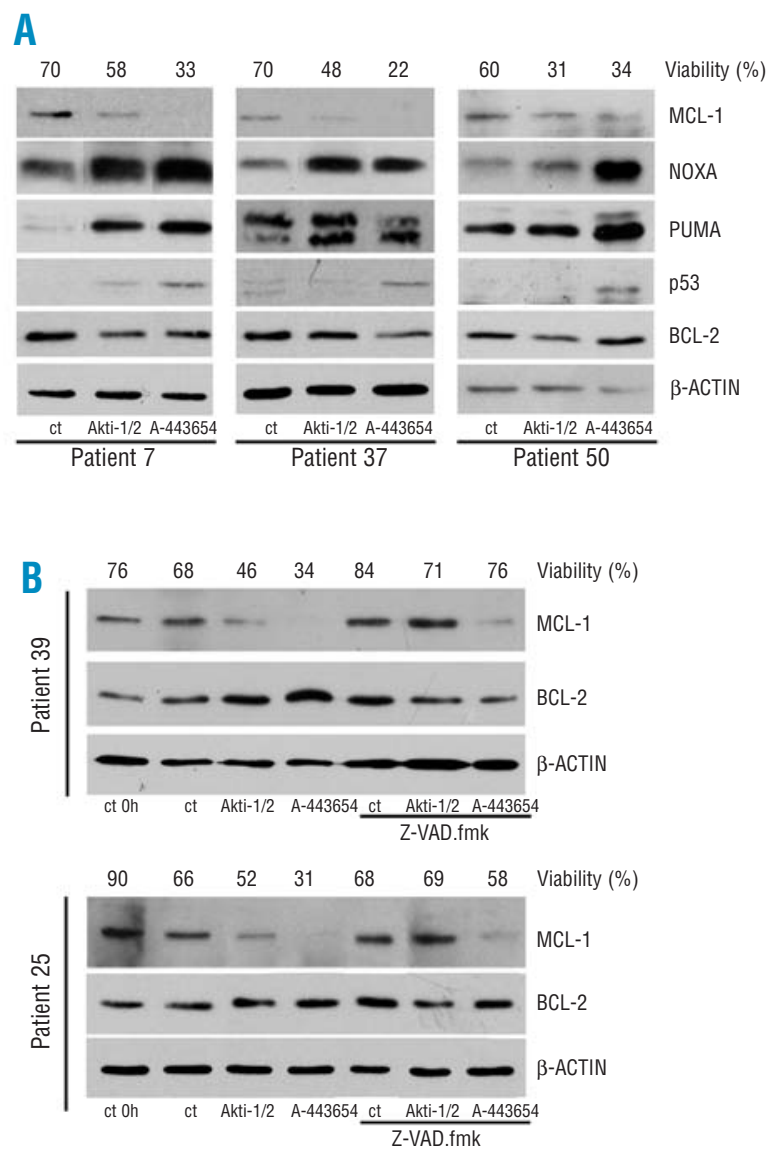

Figure 5. Apoptosis profile induced by Akti-1/2 and A-443654. (A) Apoptosis-related protein expression profile induced by Akti-1/2 and A-443654. Cells were untreated (ct) or treated with $5 \mu \mathrm{M}$ Akti$1 / 2(n=10)$ and $0.5 \mu M A-443654(n=13)$ for $24 h$, and MCL-1, NOXA, PUMA, p53 and BCL-2 expression was determined by western blot. Cell viability is expressed at the top of the figure. $\beta$-actin was used to standardize protein levels. Results from three representative patients are shown, two corresponding to Ficoll isolated cells (patients 7 and 37 ) and one corresponding to purified CD19+ CLL cells (patient 50). (B) Effect of Z-VAD.fmk on Akti-1/2 and A443654-induced MCL-1 decrease. Cells were pretreated with or without $200 \mu \mathrm{M}$ Z-VAD.fmk for $30 \mathrm{~min}$ and then treated with $5 \mu \mathrm{M}$ Akti-1/2 and $0.5 \mu \mathrm{M} \mathrm{A}-443654$ for $24 \mathrm{~h}$ (results from two representative patients are shown, $n=3$ ), and MCL-1 levels were determined by western blot. BCL-2 and $\beta$-actin were used to standardize protein levels. Cell viability is expressed at the top of the figure.
Akti-1/2 for $24 \mathrm{~h}$ did not induce any significant change in the RT-MLPA profile (Figure 4 and Online Supplementary Figure S6A). The results indicated that Akt inhibition has minimal effects on the apoptosis mRNA expression profile. Surprisingly, incubation of CLL cells with $0.5 \mu \mathrm{M}$ A-443654 for $24 \mathrm{~h}$ induced an increase in the mRNA levels of NOXA and PUMA and a decrease in the mRNA levels of $B M F, B I D$, one $B A X$ probe, BCLw, NAIP, AIF, APAF and $A P A F_{L}$ (Figure 4 and Online Supplementary Figure $S 6 B$ ). Similar results were obtained in purified CD19+ CLL cells (Online Supplementary Figure S7). Thus, A-443654-induced mRNA changes are likely independent of its activity of inhibiting Akt.

We then investigated the effect of Akt inhibitors on the expression of BCL-2 family proteins. Western blot analysis revealed that Akti-1/2 and A-443654 increased
A
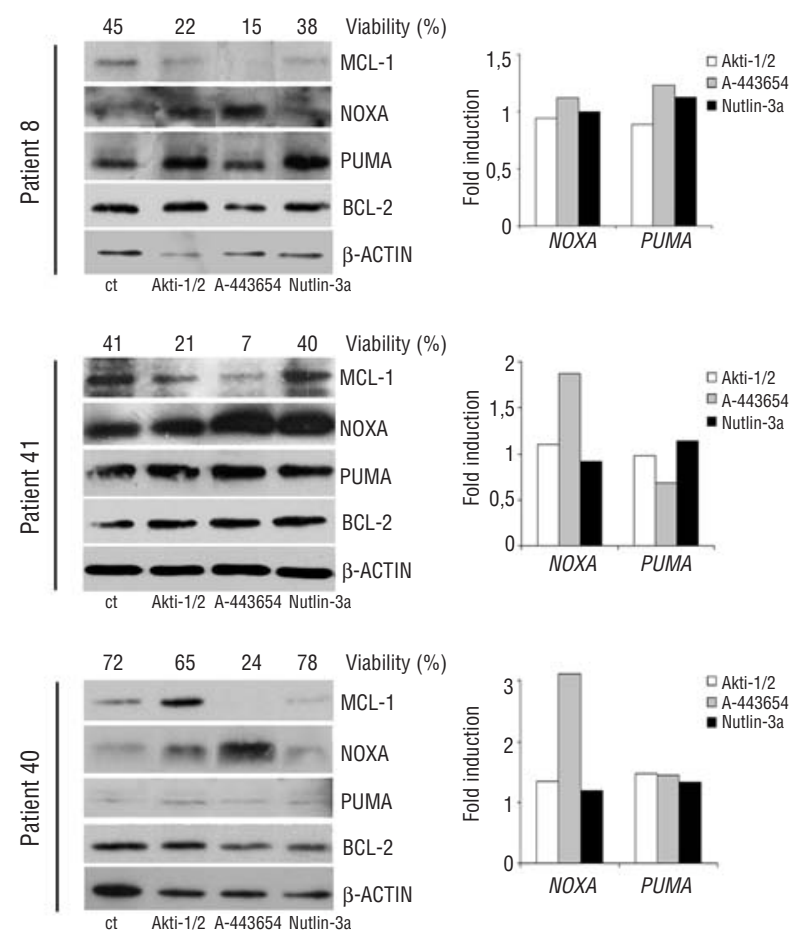

Figure 6. Apoptosis profile induced by Akti-1/2 and A-443654 in TP53 deleted/mutated samples. (A) Protein expression profile and cytotoxic effect of Akti-1/2, A-443654 and Nutlin-3a. Cells were untreated (ct) or treated with $5 \mu \mathrm{M}$ Akti-1/2, $0.5 \mu \mathrm{M}$ A443654 or $5 \mu \mathrm{M}$ Nutlin-3a for $24 \mathrm{~h}$, and MCL-1, NOXA and PUMA expression was determined by western blot. BCL-2 and $\beta$-actin were used to standardize protein levels. Viability was measured by analysis of phosphatidylserine exposure and propidium iodide uptake as described in the Design and Methods section. (B) Apoptosis-related gene expression profile induced by Akti-1/2 and A-443654 in TP53 deleted/mutated CLL samples. Cells were untreated or treated with $5 \mu \mathrm{M}$ Akti-1/2 (white filled bars) or 0.5 $\mu \mathrm{M}$ A-443654 (gray filled bars) and $5 \mu \mathrm{M}$ Nutlin-3a (black filled bars) for $24 \mathrm{~h}$. Cells were lysed, and the expression of apoptosisrelated genes was analyzed by RT-MLPA as described in the Design and Methods section. The results are shown as fold induction relative to untreated cells. 
NOXA protein levels and decreased MCL-1 protein levels in all the samples analyzed. PUMA protein levels were also increased in $50 \%$ of the samples after treatment with Akt inhibitors (Figure 5A). Furthermore, p53 protein was increased by A- 443654 but not by Akti-1/2 in all the samples analyzed.

We further analyzed the apoptosis-related protein expression profile induced by Akti-1/2 and A-443654 at different times. We did not observe any change in MCL-1, NOXA and PUMA protein levels after $3 \mathrm{~h}$ of treatment with Akt inhibitors (data not shown). NOXA protein was increased by Akt inhibitors at $6 \mathrm{~h}$ while PUMA protein levels were increased at $12 \mathrm{~h}$. Moreover, MCL-1 protein was decreased after incubation with A-443654 for 6 h (Online Supplementary Figure S8). Finally, pretreatment with $200 \mu \mathrm{M}$ Z-VAD. fmk for 30 min blocked the decrease in MCL-1 induced by Akti-1/2 but not that induced by A- 443654 (Figure 5B). These results demonstrate that the decrease in MCL-1 induced by Akti-1/2 is caspase-dependent whereas that induced by A- 443654 is caspase-independent and precedes the activation of caspases.

\section{Akti-1/2 and A-443654 induce apoptosis irrespective of TP53 status in chronic lymphocytic leukemia cells}

To study the role of p53 in Akti-1/2 and A-443654induced apoptosis we analyzed the effect of these compounds on CLL samples with deleted/mutated TP53. Patients' samples with deleted/mutated TP53 or altered expression have been described previously. ${ }^{28-30}$ Patient 8 had a $17 \mathrm{p}$ deletion in one allele in $43 \%$ of peripheral blood lymphocytes, patient 41 had a $17 \mathrm{p}$ deletion in one allele in $94 \%$ of peripheral blood lymphocytes, and patient 40 had a frame-shift mutation in one allele (nucleotide deletion in codon 272) and a 17p deletion in the other allele in $86 \%$ of peripheral blood lymphocytes. First, we incubated these CLL cells with $5 \mu \mathrm{M}$ Akti-1/2 or $0.5 \mu \mathrm{M}$ A-443654 for $24 \mathrm{~h}$. Interestingly, we observed a decrease in viability in two of the three samples with Akti-1/2 treatment and in all three samples with A-443654 treatment (Figure 6A).

Western blot analysis revealed an increase in NOXA levels in the three samples when treated with both inhibitors, while PUMA levels increased in only one sample (patient 8) with $5 \mu \mathrm{M}$ Akti-1/2 treatment. MCL-1 levels decreased with Akti-1/2 in patients 8 and 41, where Akti-1/2 induced apoptosis. In patient 40, MCL-1 levels increased with Akti-1/2 treatment, and the inhibitor did not induce apoptosis. A-443654 treatment induced a decrease in MCL-1 levels in the three samples (Figure 6A). As a control of TP53 status we used $5 \mu \mathrm{M}$ Nutlin-3a, which has been described to induce apoptosis and p53 accumulation in cells with wild-type TP53 but not in those with deleted/mutated TP53. ${ }^{28}$

Next, we examined the apoptosis mRNA expression profile by performing RT-MLPA. Incubation with 5 $\mu \mathrm{M}$ Akti-1/2 or $0.5 \mu \mathrm{M}$ A-4436545 induced almost the same mRNA expression profile as that in CLL cells with the wild-type TP53, except that PUMA mRNA levels did not increase after treatment with A-443654 (Figure 6B).

\section{Discussion}

In this study we investigated the effect of two Akt inhibitors on the viability of CLL cells. Both Akt inhibitors induced apoptosis in primary CLL cells. These results are in agreement with a recent report describing that introduction of constitutively active myr.Akt increases the viability of CLL cells. ${ }^{31}$

The mechanism of action of the two Akt inhibitors is somewhat different (Online Supplementary Figure S9). Surprisingly, Akti-1/2 inhibits Akt but does not induce changes in the RT-MLPA profile. Akt modulates the transcriptional activity of at least one transcription factor, FoxO $3 a^{15}$ which would induce changes in the mRNA levels of its transcriptional targets $B I M^{32}$ and PUMA. ${ }^{33}$ However, RT-MLPA experiments suggest that dephosphorylation of FoxO3a induced by Akti-1/2 is not sufficient to induce the transcription of $B I M$ and PUMA in CLL cells. As A-443654 is a less specific Aktinhibitor, ${ }^{21}$ the simplest model would be to consider that inhibition of Akt (common to both inhibitors) does not induce changes in the RT-MLPA profile, and that A-443654 has additional targets to explain its effects on the expression of genes. Thus, A-443654 induces an increase in the levels of $\mathrm{p} 53$ protein and the induction of PUMA mRNA, a transcriptional target of TP53 in CLL. ${ }^{28,34}$ In agreement with these data, the induction of PUMA mRNA by A-443654 was decreased in CLL cells with deleted/mutated TP53. Interestingly, Akti-1/2 induced PUMA and NOXA proteins without affecting PUMA and NOXA mRNA. The mechanism for this effect is unknown and could be explained by increased translation or decreased proteolysis of these proteins.

A common effect of both Akt inhibitors is the modulation of NOXA/MCL-1 balance. It has been reported that in primary CLL cells, the majority of NOXA protein is associated with MCL-1. ${ }^{35}$

Thus, Akti-1/2 and A-443654 treatment induced an increase in NOXA protein levels and a down-regulation of the levels of MCL-1, a critical survival protein in CLL cells. Furthermore, inhibition of caspases prevents the down-regulation of MCL-1 induced by Akti$1 / 2$, suggesting that MCL-1 cleavage participates in an amplification loop that increases cytochrome $\mathrm{c}$ release and apoptosis in CLL cells, as described for PKC inhibitors. ${ }^{36}$ In agreement with our results, the introduction of constitutively active myr.Akt increases MCL-1 protein, and inhibition of MCL-1 by treatment with siRNA induces apoptosis in CLL. ${ }^{31}$ The mechanism of regulation of MCL-1 protein by Akt in CLL cells is unknown. The Akt substrate GSK-3 has been reported to induce destabilization of MCL-1 protein. ${ }^{16}$ However, inhibition of GSK-3 does not inhibit the apoptotic effect of PI3K inhibitors.? As GSK-3 is inhibited by $\mathrm{PKC},{ }^{37}$ perhaps the over-expression of active PKC- $\beta I^{38}$ blocks this pathway in CLL cells.

We found that B cells from CLL samples were more 
sensitive to Akt inhibitors than T cells from CLL samples, and B or $\mathrm{T}$ cells from healthy donors. Chemotherapeutic drugs, including fludarabine, chlorambucil, and doxorubicin induce apoptosis equally in both $\mathrm{B}$ and $\mathrm{T}$ cells, leading to immunosuppression. ${ }^{39,40}$ Thus, the differential effect of Akti-1/2 and A-443654 in B and $T$ lymphocytes is of interest. In conclusion, the results presented here suggest that clinically suitable small-molecule inhibitors of Akt alone or in combination with chemotherapeutic drugs might be a new therapeutic option for the treatment of CLL.

\section{Authorship and Disclosures}

MdeF performed the research and contributed to data analysis and manuscript writing. DIS, AMC, LCM, AFS and DMGG performed the research and contributed with analytical tools. EdelaB contributed with patients' samples and data. GP designed the research and contributed to data analysis. JG designed the research and contributed to data analysis and manuscript writing. The authors reported no potential conflicts of interest.

\section{References}

1. Barragan M, Campas C, Bellosillo B, Gil J. Protein kinases in the regulation of apoptosis in B-cell chronic lymphocytic leukemia. Leuk Lymphoma 2003;44:1865-70.

2. Barragan M, Bellosillo B, Campas C, Colomer D, Pons G, Gil J. Involvement of protein kinase $C$ and phosphatidylinositol 3-kinase pathways in the survival of B-cell chronic lymphocytic leukemia cells. Blood 2002;99:2969-76.

3. Bernal A, Pastore RD, Asgary Z, Keller SA, Cesarman E, Liou HC, et al. Survival of leukemic B cells promoted by engagement of the antigen receptor. Blood 2001;98:3050-7.

4. Ringshausen I, Schneller F, Bogner C, Hipp S, Duyster J, Peschel C, et al. Constitutively activated phosphatidylinositol-3 kinase (PI-3K) is involved in the defect of apoptosis in B-CLL: association with protein kinase CA. Blood 2002;100:3741-8.

5. Jones DT, Ganeshaguru K, Anderson RJ, Jackson TR, Bruckdorfer KR, Low SY, et al. Albumin activates the AKT signaling pathway and protects B-chronic lymphocytic leukemia cells from chlorambucil- and radiation-induced apoptosis. Blood 2003; 101:3174-80

6. Cuni S, Perez-Aciego P, PerezChacon G, Vargas JA, Sanchez A, Martin-Saavedra FM, et al. A sustained activation of PIBK/NFkappaB pathway is critical for the survival of chronic lymphocytic leukemia B cells. Leukemia 2004;18: 1391-400.

7. Plate JM. PI3-kinase regulates survival of chronic lymphocytic leukemia B-cells by preventing caspase 8 activation. Leuk Lymphoma 2004:45:1519-29.

8. Nedellec S, Renaudineau Y, Bordron A, Berthou C, Porakishvili N, Lydyard PM, et al. B cell response to surface IgM cross-linking identifies different prognostic groups of Bchronic lymphocytic leukemia patients. J Immunol 2005; 174: 374956.

9. Hu X, Haney N, Kropp D, Kabore AF, Johnston JB, Gibson SB. Lysophosphatidic acid (LPA) pro- tects primary chronic lymphocytic leukemia cells from apoptosis through LPA receptor activation of the anti-apoptotic protein AKT/PKB. J Biol Chem 2005;280: 9498-508.

10. Barragan M, de Frias M, IglesiasSerret D, Campas C, Castano E, Santidrian AF, et al. Regulation of Akt/PKB by phosphatidylinositol 3kinase-dependent and -independent pathways in B-cell chronic lymphocytic leukemia cells: role of protein kinase C $\beta$. J Leukoc Biol 2006;80: 1473-9.

11. Petlickovski A, Laurenti L, Li X, Marietti S, Chiusolo P, Sica S, et al. Sustained signaling through the Bcell receptor induces Mcl-1 and promotes survival of chronic lymphocytic leukemia B cells. Blood 2005; 105:4820-7.

12. Engelman JA, Luo J, Cantley LC. The evolution of phosphatidylinositol 3-kinases as regulators of growth and metabolism. Nat Rev Genet 2006;7:606-19.

13. Leupin N, Cenni B, Novak U, Hugli B, Graber HU, Tobler A, et al. Disparate expression of the PTEN gene: a novel finding in B-cell chronic lymphocytic leukaemia (B-CLL). Br J Haematol 2003;121:97-100.

14. Manning BD, Cantley LC. AKT/PKB signaling: navigating downstream. Cell 2007;129:1261-74.

15. Brunet A, Bonni A, Zigmond MJ, Lin MZ, Juo P, Hu LS, et al. Akt promotes cell survival by phosphorylating and inhibiting a Forkhead transcription factor. Cell 1999;96:85768.

16. Maurer U, Charvet C, Wagman AS, Dejardin E, Green DR. Glycogen synthase kinase-3 regulates mitochondrial outer membrane permeabilization and apoptosis by destabilization of MCL-1. Mol Cell 2006; 21:749-60.

17. Longo PG, Laurenti L, Gobessi S, Petlickovski A, Pelosi M, Chiusolo P, et al. The Akt signaling pathway determines the different proliferative capacity of chronic lymphocytic leukemia B-cells from patients with progressive and stable disease. Leukemia 2007;21:110-20.

18. Luo Y, Shoemaker AR, Liu X, Woods KW, Thomas SA, de Jong R, et al. Potent and selective inhibitors of Akt kinases slow the progress of tumors in vivo. Mol Cancer Ther 2005;4:977-86.

19 Shi Y, Liu X, Han EK, Guan R, Shoemaker AR, Oleksijew A, et al. Optimal classes of chemotherapeutic agents sensitized by specific small-molecule inhibitors of akt in vitro and in vivo. Neoplasia 2005; 7:992-1000.

20. Han EK, Leverson JD, McGonigal T, Shah OJ, Woods KW, Hunter T, et al. Akt inhibitor A-443654 induces rapid Akt Ser-473 phosphorylation independent of mTORC1 inhibition. Oncogene 2007;26:5655-61.

21. Bain J, Plater L, Elliott M, Shpiro N, Hastie CJ, McLauchlan H, et al. The selectivity of protein kinase inhibitors: a further update. Biochem J 2007;408:297-315.

22. Barnett SF, Defeo-Jones D, Fu S, Hancock PJ, Haskell KM, Jones RE, et al. Identification and characterization of pleckstrin-homologydomain-dependent and isoenzymespecific Akt inhibitors. Biochem J 2005;385:399-408.

23. Logie L, Ruiz-Alcaraz AJ, Keane M, Woods YL, Bain J, Marquez R, et al. Characterization of a protein kinase $B$ inhibitor in vitro and in insulintreated liver cells. Diabetes 2007;56: 2218-27.

24. Bellosillo B, Pique M, Barragan M, Castano E, Villamor N, Colomer D, et al. Aspirin and salicylate induce apoptosis and activation of caspases in B-cell chronic lymphocytic leukemia cells. Blood 1998; 92:140614.

25. Eldering E, Spek CA, Aberson HL, Grummels A, Derks IA, de Vos AF, et al. Expression profiling via novel multiplex assay allows rapid assessment of gene regulation in defined signalling pathways. Nucleic Acids Res 2003;31:e153.

26. Dancescu M, Rubio-Trujillo M, Biron G, Bron D, Delespesse G, Sarfati M. Interleukin 4 protects chronic lymphocytic leukemic B cells from death by apoptosis and upregulates Bcl-2 expression. J Exp Med 1992;176:1319-26.

27. Burger JA, Tsukada N, Burger M, Zvaifler NJ, Dell'Aquila M, Kipps TJ. Blood-derived nurse-like cells pro- 
tect chronic lymphocytic leukemia B cells from spontaneous apoptosis through stromal cell-derived factor1. Blood 2000;96:2655-63.

28. Coll-Mulet L, Iglesias-Serret D, Santidrian AF, Cosialls AM, de Frias M, Castano E, et al. MDM2 antagonists activate p53 and synergize with genotoxic drugs in B-cell chronic lymphocytic leukemia cells. Blood 2006;107:4109-14.

29. Coll-Mulet L, Santidrian AF, Cosialls AM, Iglesias-Serret $D$, de Frias $M$, Grau J, et al. Multiplex ligationdependent probe amplification for detection of genomic alterations in chronic lymphocytic leukaemia. Br J Haematol 2008;142:793-801.

30. Santidrian AF, Cosialls AM, CollMulet L, Iglesias-Serret D, de Frias M, Gonzalez-Girones DM, et al. The potential anticancer agent PK11195 induces apoptosis irrespective of p53 and ATM status in chronic lymphocytic leukemia cells Haematologica 2007;92:1631-8.

31. Longo PG, Laurenti L, Gobessi S, Sica S, Leone G, Efremov DG. The Akt/Mcl-1 pathway plays a promi- nent role in mediating antiapoptotic signals downstream of the B-cell receptor in chronic lymphocytic leukemia B cells. Blood 2008;111: 846-55.

32. Dijkers PF, Medema RH, Lammers JW, Koenderman L, Coffer PJ. Expression of the pro-apoptotic Bcl2 family member $\mathrm{Bim}$ is regulated by the forkhead transcription factor FKHR-L1. Curr Biol 2000;10:1201-4.

33. You $\mathrm{H}$, Pellegrini M, Tsuchihara K, Yamamoto K, Hacker G, Erlacher M, et al. FOXO3a-dependent regulation of Puma in response to cytokine/growth factor withdrawal. J Exp Med 2006;203:1657-63.

34. Mackus WJ, Kater AP, Grummels A, Evers LM, Hooijbrink B, Kramer $\mathrm{MH}$, et al. Chronic lymphocytic leukemia cells display p53-dependent drug-induced Puma upregulation. Leukemia 2005;19:427-34.

35. Hallaert DY, Spijker R, Jak M, Derks IA, Alves NL, Wensveen FM, et al. Crosstalk among Bcl-2 family members in B-CLL: seliciclib acts via the Mcl-1/Noxa axis and gradual exhaustion of $\mathrm{Bcl}-2$ protection. Cell
Death Differ 2007;14:1958-67.

36. Snowden RT, Sun XM, Dyer MJ, Cohen GM. Bisindolylmaleimide IX is a potent inducer of apoptosis in chronic lymphocytic leukaemic cells and activates cleavage of Mcl-1. Leukemia 2003;17:1981-9.

37. Christian SL, Sims PV, Gold MR. The B cell antigen receptor regulates the transcriptional activator $\beta$ catenin via protein kinase $C$-mediated inhibition of glycogen synthase kinase-3. J Immunol 2002;169:75869.

38. Abrams ST, Lakum T, Lin K, Jones GM, Treweeke AT, Farahani M, et al. B-cell receptor signaling in chronic lymphocytic leukemia cells is regulated by overexpressed active protein kinase CBII. Blood 2007;109: 1193-201.

39. Keating MJ. Immunosuppression with purine analogues - the flip side of the gold coin. Ann Oncol 1993; 4:347-8.

40. Hamblin AD, Hamblin TJ. The immunodeficiency of chronic lymphocytic leukaemia. Br Med Bull 2008;87:49-62. 